\title{
Platform "Profosvita" as innovative educational and digital environment for specialists' professional development
}

\author{
Viktoriia V. Sydorenkoi \\ University of Educational Management, Bila Tserkva, Ukraine
}

Andriy B. Yermolenkoii

University of Educational Management, Bila Tserkva, Ukraine

\author{
Alla M. Lukiianchukiii \\ University of Educational Management, Bila Tserkva, Ukraine \\ Anastasiia V. Denysovaiv \\ University of Educational Management, Bila Tserkva, Ukraine \\ Vira Ye. Kharagirlov \\ University of Educational Management, Bila Tserkva, Ukraine
}

\begin{abstract}
The article substantiates organizational and methodological principles of the Educational platform "Profosvita" as an innovative educational and digital environment to ensure the continuous professional development of specialists in accordance with the requirements of the state policy in the field of education, of employers and key stakeholders, as well as to meet educational needs of an individual as educational services customer. The Educational platform "Profosvita" developers summarized and systematized theoretical assets and took into account the latest tendencies of platforms creation for distance and mixed training. The proposed structure of the educational-digital environment provides mastery for learners, customers of educational services of different directions and specialties of certain theoretical and practical aspects of educational courses, educational headings. The presentative and educational locations are described as the main elements of the Educational platform "Profosvita" structure, forms of participant participation, principles of work organization. The research results can be used in the modernization process of postgraduate education system, in particular in the activity of postgraduate education institutions of all levels of accreditation, district methodical services for organization of continuous professional development of specialists in the conditions of sustainable development of education and science.
\end{abstract}

\section{Keywords}

Sustainable development. Digital competence. Technologies. Modernization. Postgraduate education. 


\title{
Plataforma "Profosvita" como um ambiente educacional e digital inovador para o desenvolvimento profissional de especialistas
}

\begin{abstract}
Resumo
O artigo substancia os princípios organizacionais e metodológicos da plataforma educacional "Profosvita" como um ambiente educacional e digital inovador para garantir o desenvolvimento profissional contínuo de especialistas, de acordo com os requisitos da política estadual no campo da educação, dos empregadores e das principais partes interessadas, bem como atender às necessidades educacionais de um indivíduo como cliente de serviços educacionais. Os desenvolvedores da plataforma educacional "Profosvita" resumiram e sistematizaram ativos teóricos e levaram em conta as últimas tendências de criação de plataformas para treinamento a distância e misto. A estrutura proposta para o ambiente digital educacional fornece domínio para alunos, clientes de serviços educacionais de diferentes direções e especialidades de certos aspectos teóricos e práticos dos cursos educacionais e títulos educacionais. Os locais presencial e educacional são descritos como os principais elementos da estrutura da plataforma educacional "Profosvita", formas de participação dos participantes, princípios de organização do trabalho. Os resultados da pesquisa podem ser utilizados no processo de modernização do sistema de ensino de pós-graduação, em particular na atividade de instituições de ensino de pós-graduação de todos os níveis de certificação, serviços metódicos distritais para a organização do desenvolvimento profissional contínuo de especialistas nas condições de desenvolvimento sustentável da educação e da educação e ciência.
\end{abstract}

\section{Palavras-chave}

Desenvolvimento sustentável. Competência digital. Tecnologias. Modernização. Pós-graduação.

\section{Plataforma "Profosvita" como ambiente educativo e innovador digital para el desarrollo profesional de especialistas}

\begin{abstract}
Resumen
El artículo respalda los principios organizativos y metodológicos de la plataforma educativa "Profosvita" como un entorno educativo y digital innovador para garantizar el desarrollo profesional continuo de especialistas de acuerdo con los requisitos de la política estatal en el campo de la educación, de los empleadores y las partes interesadas clave, así como para satisfacer las necesidades educativas de un individuo como cliente de servicios educativos. Los desarrolladores de la plataforma educativa "Profosvita" resumieron y sistematizaron los activos teóricos y tomaron en cuenta las últimas tendencias en la creación de plataformas para la formación a distancia y mixta. La estructura propuesta del entorno educativo-digital proporciona dominio para los estudiantes, clientes de servicios educativos de diferentes direcciones y especialidades de ciertos aspectos teóricos y prácticos de cursos educativos, títulos educativos. Las ubicaciones presentativas y educativas se describen como los elementos principales de la estructura de la plataforma educativa "Profosvita", formas de participación de los participantes, principios de organización del trabajo. Los resultados de la investigación se pueden utilizar en el proceso de modernización
\end{abstract}


del sistema educativo de posgrado, en particular en la actividad de las instituciones de educación de posgrado de todos los niveles de acreditación, servicios metódicos distritales para la organización del desarrollo profesional continuo de especialistas en las condiciones de desarrollo sostenible de la educación y ciencias.

\section{Palabras clave}

Desarrollo sostenible. Competencia digital. Tecnologías. Modernización. Posgrado.

\section{Introduction}

New educational reality, in particular the digitization of education and creation of open educational space of the New Ukrainian School, requires modernization of postgraduate education content and formation of relevant open content, which implies valuable use of knowledge, development of modern specialists' key competences, cognitive abilities and critical intelligence, their lifelong social integration and social activity via formal, non-formal and informal education. The project "Ukraine Digital Agenda - 2020: conceptual frameworks (version 1.0)" states that digitalization will become the basis of Ukrainian society life, business and government agencies, our common and everyday phenomenon, our DNA, the key agenda for Ukraine prosperity and well-being (PROJECT, 2020). New model of the society of knowledge development requires from a modern specialist a wide range of skills and competencies to successfully fulfill his professional functions to ensure comprehensive and sustainable development of Ukraine education and science. Education is turning into a continuous system of training knowledge workers, who work with knowledge and information flows and are able to valuably use them for qualitative fulfillment of new professional roles and functions (SYDORENKO; KOVALCHUK, 2019).

It is not for nothing that digital literacy (or digital competence) is recognized by the EU as the key one to a person's fruitfull life and activity. "The Law on Education" (UKRAINE, 2017) states that the formation of information and communication competence is obligatory. Among the key competences of the New Ukrainian School teacher the information-digital competence is being stressed (GOVERNMENT, 2018; HRYSHCHENKO, 2017; STATE, 2014).

The Framework for the renewed key competences for lifelong learning, endorsed by the European Parliament and the European Union Council on January 17, 2018 (A 
MEMORANDUM, 2000; ANNEX, 2019; FRAMEWORK, 2019), interprets Digital competence as a confident, critical and responsible use and engagement with digital technologies for learning, professional activity and participation in society life, includes digital and information literacy, communication and collaboration, digital content creation, cybersecurity and problem solving; ability to use digital technologies to support creativity, active citizenship and social integration, collaboration with other people to achieve personal, social goals, etc.

European reference frameworks define the core competence of digital media as a confident and critical use of Information Society (IST) Technologies for work, leisure and communication. This social order actualizes the need to train specialists who meet challenges of the society of knowledge, are capable of continuous intellectual, cultural and spiritual development. Modern era, coinciding with the fourth industrial revolution, is characterized by wide implementation of digital technologies in all spheres of human life, by fusion of the material world with the virtual one, resulting in creation of new cyberphysical components, combined into a single digital system. The leading features of this system are: the ability of subjects to cooperate and coexist; space virtualization; transparency; network interaction; use of digital technologies and more (FRITH; DE JONG; VANSTEENHUYSE, 2012).

The Educational platform "Profosvita" is an innovative educational-digital environment for continuous professional development of specialists via formal, nonformal and informal education. The Educational platform "Profosvita" (PROFESSIONAL, 2020 ) is an innovative educational-digital environment that combines the intellectual, scientific, professional, educational, technological potential of subjects to ensure the quality of digital-based education in the virtual space. The Ukraine Law "On Education" interprets quality of education as the conformity of training results with the requirements, established by law, the corresponding standard of education and / or contract on educational services provision; the educational activity quality implies the level of organization, provision and implementation of the educational process, ensuring persons the acquisition of quality education and meeting the requirements, established by law and / or contract on educational services provision (THE CONCEPT, 2019 UKRAINE, 2017, 2018).

Educ. Form., Fortaleza, v. 5, n. 3, p. 1-17, set./dez. 2020 
Topicality of using the Educational platform "Profosvita" as educational and digital environment in the process of training, professional development and retraining of specialists is to develop the educational services customers with key competencies, to develop skills of using information and communication tools, to increase the volume of information, to create their own electronic products, to build own communication style, to be the basis for learning and successful professional activity. The educational-digital environment promotes motivation for lifelong learning, independence, helps to better understand and absorb learning content. In such environment, it is possible to conduct refresher training for different categories of learners, to provide training for students, to organize scientific conferences, internships and exchange of experience between specialists. The educational-digital environment includes learning tools, developed and implemented on the basis of interactive and digital technologies.

The article purpose is to substantiate organizational and methodological foundations of the Educational platform "Profosvita" as innovative educational-digital environment for the continuous professional development of specialists via formal, nonformal and informal education. According to the stated goal, the main tasks of research are defined as follows: 1) to determine purpose, tasks and discipline profiles of the Educational platform "Profosvita"; 2) to analyze the principles of building educational content of the Educational platform "Profosvita"; 3) to describe the presentative and educational locations as the basic elements of the Educational platform "Profosvita" structure, forms of member participation, principles of work organization; 4) to find out the possibilities of using the Educational platform "Profosvita" for professional development of specialists in the conditions of formal, non-formal and informal education.

\section{Profosvita platform description}

In the virtual space, a site, that is an educational content management system called the Educational platform "Profosvita", located at Professional Education (2020). It is displayed and functioning according to the task in all browsers and is adapted for mobile devices with iOS, Android and Windows Phone operating systems. The site interface may differ in some small details: rounded corners, shadow level, gradient or solid fill. The color scheme, the elements layout, the site structure remains the same. 
During the Educational platform "Profosvita" development, the theoretical experiences were generalized and systematized and the latest tendencies of creation the distance and mixed learning platforms were taken into account. The proposed structure provides learning theoretical and practical aspects of educational courses for learners of different dimentions and specialties. The Educational platform "Profosvita" functions as a virtualintegrated community of creative, socially-active specialists in the cross-curricular and transdisciplinary field, domestic and foreign educators, it carries out educational, scientific, methodical and organizational activities, oriented at the creation of free knowledge base, sharing the best educational practices.

The Educational platform "Profosvita" as a virtual union of technological and intellectual capital is a dynamic formation of scientists, departments, institutes, higher education institutions, public organizations, etc., characterized by independence of its participants, by use of indirect management mechanism (delegation of authority), by transition from individual to collective responsibility of its partners, which implies the existence of contractual relations between all the participating partners. Thus, as a union of real and virtual structures, the Educational platform "Profosvita" has a learner, it can enhance benefits and compensate some shortcomings in staffing and scientific/methodological provision of lifelong learning, nurturing traditions, generalizing and implementing perspective pedagogic experience. Open content of the Educational platform "Profosvita" is built with the following basic principles in mind:

- mass character and accessibility. Open content of the platform "Profosvita" has practically limitless possibilities of wide coverage of all categories of educational services customers with access for representatives of non-formal education, key stakeholders, organization of free access to information and educational resources, developed by scientific and pedagogical staff;

- adaptability and flexibility. Wide range of opportunities of the platform "Profosvita" for adaptation to changing environmental conditions, to significant transformations of all elements of educational process; flexible system of knowledge acquisition, accessible to all, without educational requirements and regulation of periodicity and training duration;

- international character and globalization. Free functioning of electronic educational resources outside state borders; 
- openness of information and educational resources, possibility to communicate, interact on-line (group webinars and individual consultations);

- modular structure and asynchronic character. The modular principle of content design and educational process organization makes it possible to predict and realize the professional development of specialists by individual educational trajectory, taking into account professional needs and possibilities, competence experience, social and educational challenges, as well as to spread in time different elements of educational process;

- economic efficiency. Educational output is achieved with less costs as compared with traditional training, time, etc.

Professional requests and needs of advanced training participants were realized due to the Bank of psychological and andragogic diagnostics (feedback questionnaires after each module/topic/course, complex questionnaires, blitz polls, tests, self-testing, computer diagnostics, interviews, etc.), selection of relevant monitoring methods on professional lifelong development of experts for the course period.

A prepared set of such monitoring procedures enables to measure, trace and diagnose the acmeological dynamics of teachers' professional development according to the following dimensions: 1) learning the needs of education service customers, that is the needs in the key competence development which are provided by the prognostic functional framework and which are important for successful fulfilment of professional goals, innovative roles and functions; 2) identifying the physiological and psychological characteristics of trainees (energy level, physical activity, performance of excitatory system, motivation and creativity, temperament type, etc.);3) identifying the cognitive and learning style, etc.

\section{Results and discussion}

The inauguration of the Educational platform was held on November 03 at the "Forum of Non-Formal Education Adult Education and Civil Society Development" in Kyiv. By the end of January 2020, there were registered 3534 participants. The Educational platform "Profosvita" solves the following tasks (SIDORENKO, 2017; SIDORENKO;

Educ. Form., Fortaleza, v. 5, n. 3, p. 1-17, set./dez. 2020 
PONOMAREVSKYI, 2018; SYDORENKO, 2018; SYDORENKO; DENYSOVA, 2020; SYDORENKO; ILLIAKHOVA; PONOMAREVSKYI, 2019):

- ensuring the continuing professional development for specialists in accordance with the requirements of state education policy, employers and key stakeholders, as well as meeting the individual educational needs of the educational services' consumer;

- involvement into virtual space of potential partners of the scientific, methodological and practical sphere for solving topical problems of professional development of specialists in accordance with socio-economic transformations in the context of the knowledge society;

- promoting the self-development and self-education of specialists by organization of network interaction, exchange of experience, training and coeducation of the community members and other citizens in the conditions of formal and non-formal education;

- development and approbation of optional educational models for adult training, taking into account the requests and needs of scientific and pedagogical staff on content structuring, selection of technologies and taking into account the existing information and network interaction of all individuals;

- scientific-pedagogical, organizational, methodological, informationalcommunicational support of professional development of specialists within educational models of refresher training courses and self-training period as a single andragogical cycle;

- providing advisory, scientific and methodological assistance to postgraduate education institutions, departments, teachers, other postgraduate education structures and non-government organizations on adult education issues in Ukraine by joint educational events (trainings, round tables, seminars, conferences, webinars, video-conferences, coaching sessions, etc.);

- dissemination of information and provision of open access to research, scientific and methodological guides, made on the basis of the Educational platform "Profosvita";

- study, analysis, generalization and promotion of innovative methods in formal and non-formal adult education; 
- facilitating interaction between nonprofit organizations and society, the mass media, local governments and commercial entities to develop adult education system.

The discipline profiles of the Educational platform "Profosvita" are: adult education philosophy; history of formal, non-formal and informal education; inclusive adult education; methodology of professional development of andragogues; scientific and methodological support of specialists' professional development; monitoring the results of professional development of specialists. The Educational platform "Profosvita" is a network-based educational-digital innovation environment that utilizes educational technologies with a multidisciplinary approach. The Educational platform "Profosvita" as a self-organizing system for providing open access to research carried out within the mentioned community, anticipates the use of remote communication network; consistent formation of virtual virtual community of specialists; marketing of knowledge and distance education services; its members intellectual property protection; integration of extensive educational practices into a holistic system of continuous professional development of specialists.

Among the Educational platform "Profosvita" advantages we differenciate the following: participants' awareness of need for each other's experience and resources, pooling resources on this basis to achieve common goals; electronic integration of the best developments; cooperation and coordination of remote partners; the ability to respond flexibly to educational environment changes, the labor market changes; implementation of an interdisciplinary learning strategy; possibility of individual training, training of persons with special educational needs, etc.

The main elements of the Educational platform "Profosvita" structure are presentative location and educational location. The presentative location of the Educational platform "Profosvita" contains a slider with the latest news in the form of a web design element containing a fixed-width block in the site header. Special features contain elements with manual or automatic change, including images, texts and links. The presentative location of the Educational platform "Profosvita" contains permanent educational columns for informal education of specialists, their lifelong self-study and selfdevelopment. For example, the educational heading "Educational Trends" is devoted to the analysis and description of current trends in the development of education, to the discussion of social and scientific transformations forecasts. The Educational heading 
"International Internship" contains academic mobility programs for learners, programs and materials of scientific internships for scientific and pedagogical staff. Theoretical information is presented in the form of text, multimedia presentations, video content, practice is supported by interactive tasks and training test simulators, tasks for independent work, etc.

Educational heading "Digital Storytelling" contains stories of interesting digital stories, to be used by teachers, psychologists, marketers, politicians, journalists, doctors and specialists of other professions. Digital storytelling in education is based on the interaction of three components: pedagogy, the latest digital technologies and content. Educational section "Professional development of the New Ukrainian School teacher" contains materials (videos of events, presentations, textual materials) concerning the substantiation of philosophical and educational foundations of the New Ukrainian School; organization of effective and safe educational environment on the basis of competency approach, partnership pedagogy, positive psychology and philosophy of child-centered education; teaching and learning features, etc. Educational headings are devoted for public access of unregistered users. They are dynamic. Content moderators can change their names and content.

The representation location also contains a questionnaire "Study of educational inquiries and needs of educational services' customers" to ensure the quality of educational services during the self-learning period. The study of professional inquiries and needs of listeners is done by the developed and tested Bank of Psycho-Andragogical Diagnostics, which includes reflectional questionnaires after each module/topic/special course, complex questionnaires, blitz surveys, tests, self-tests, computer diagnostics, interviewing. Quantitative and qualitative analysis of the experiment results is carried out by means of mathematical processing and pedagogical interpretation of the obtained experimental data. Popular courses are presented as a special web design element called "Course Carousel" and have fixed-width blocks at the bottom of the site.

The educational location contains categories of learners (research fellows, teaching staff, methodical services of all levels, etc.) with the personal web resources of tutors, teachers and content curators, based on digital educational courses. For example, the category of the Bila Tserkva Institute of Continuing Professional Education contains the following list of subcategories: Department of Pedagogy, Psychology and 
Management; Department of Methods of Vocational Education, Social Disciplines and Humanities; Department of Training Technologies, Labor Safety and Design. Each category has its own subcategories with personal web resources. In particular, the Department of Training Technologies, Labor Safety and Design contains personal webbased resources of the department's educators. Accordingly, each web resource has digital education courses with a specific template. The template content must include the tutor's welcome word in the form of a short video, curriculum, and tests for the appropriate levels of course learning. The material is presented in a textual form, accompanied by presentations, audio and video materials. The educational process is done by using webinars, held in separate rooms for each category, including bigbluebutton, wiziq, etc. A tutor has a possibility to supplement his material with gamification elements, using online services, such as leaningapps. The course and selflearning periods feedback is done by thematic forums and individual correspondence, provided by the content management system functioning. If necessary, there are conducted surveys and online interviews, such as the resource (OVR, 2020). The educational process is monitored with the help of the educational content management toolkit by the course activity, amount of time spent, etc.

In the web resource, all tasks are built on the basis of a competency approach with embedding competencies after passing and forming an overall competency value. Learning outcomes are reflected in the assessment log and provide statistics that allow teachers to regulate the learning content delivery and content itself. The course theoretical information is presented in the form of text, multimedia presentations, video content, practice is supported by interactive tasks and training test simulators, etc. Study material is grouped by modules. Each module has tasks that ensure the development of competencies needed to master the material. The modules are also backed up by tests and interactive tasks. They contain extensive tools for training content delivery and feedback, such as chats, forums, profiles.

In the educational course, the thematic and didactic content can be edited by a teacher, depending on the needs of learners, recipients of education. These needs are identified by monitoring of scores and statistics of course delivery in the conditions of electronic educational resource. When a user enters into a software product, he / she is taken to the main page, after that he / she enters login and password and goes to training 
courses. The navigation and control panels make it possible to perform tasks in a learnerfriendly manner and to make changes to the teaching content by teachers.

The Educational platform "Profosvita" anticipates the following participation forms: the legitimate peripheral participation (LPP) of participants, determined on the basis of Agreements on scientific cooperation with other structures of virtual educational cluster, and by modified form of participation, which gives a possibility for community non-members to participate in the activity. Taking into account the geographical distance of its partnersparticipants, it is envisaged to use internal organizational, mixed and inter-organizational forms of organizational work, including trainings, round tables, seminars, internet conferences, a knowledge bank; webinars, chats, video conferences; online studios, web laboratories, web colleges, pedagogical web quests, etc. Electronic educational resources are a major component of the open educational-digital environment of the Educational platform "Profosvita", which focuses on the qualitative organization of the educational process via digital technologies and application of new methods and forms of adult training, in particular e-training; mobile training; network training; mixed training; flipped training, etc.

Under the electronic educational resources (EER), in accordance with the Regulations on Electronic Educational Resources of the Ukraine Ministry of Education and Science (REGULATION, 2019), we understand educational, scientific, informative, reference materials and tools, developed in electronic form and available on any type memory or placed in computer networks, which are reproduced by means of electronic digital technical means and are necessary for effective organization of educational process, in the part, concerning its filling with qualitative educational and methodical materials. Open Educational Resources (OER) provide educational services' customers with access to course materials, modules, textbooks, videos, tests, any other tools, materials or methods, and are used to support access to knowledge.

\section{Conclusions}

The use of open content, open educational resources makes it possible to significantly expand educational environment, to ensure formation and use of open educational space for all consumers of information, opens additional opportunities for the development of key competences of educational services' customers. Methodology of 
using the Educational platform "Profosvita" for the continuous development of specialists is divided into several parts: general recommendations, use of electronic educational resource tools, embedding competencies into a course and learning outcomes monitoring. The educational platform "Profosvita" can be used in the system in the following ways.

Formal postgraduate education - in the educational process of refresher training courses by different models and forms of education (specialization, internships, retraining) in postgraduate educational establishments, at all stages of self-learning period, as well as in the system of scientific and methodological work with pedagogical staff at the local level (in the system of scientific and methodological work of district (city) methodical offices (centers), united territorial communities.

Non-formal education - during various forms of work, carried out in the context of educational initiatives (in particular by public organizations, educational centers, foundations, other entities, as well as during individual classes under the guidance of andragogues, coaches and supervisors) and aims to develop additional skills and competences.

In informal education - in the process of self-organized education, self-education of educational services' customers and key stakeholders in order to transform the educational potential of the knowledge society into effective factors of their own selfdevelopment, acquiring new competencies.

\section{Acknowledgements}

The research results were obtained in accordance with the research thematic plan of the Department of Philosophy and Adult Education of the Central Institute of Postgraduate Education at the State Higher Education Establishment "Education Management University" at the Ukraine National Academy of Pedagogical Sciences on the topic "Professional development of specialists in the adult education system: history, theory, technologies" (RN 0117U002381, 2017-2019), a complex theme of research of the Bila Tserkva Institute of Continuing Professional Education: "Improvement of modern models of vocational education teachers refresher training in the context of formation and development of professional competence" (registration number 0117U002381, 2017-2021). 


\section{References}

A MEMORANDUM on Lifelong Learning. Commission of the European communities. 2000. Retrieved from: http://arhiv.acs.si/dokumenti/Memorandum_on_Lifelong_Learning.pdf. Accessed on: Jan. 20, 2020.

ANNEX to the Proposal for a Council Recommendation on Key Competences for Lifelong Learning. 2019. Retrieved from:

https://ec.europa.eu/education/sites/education/files/annex-recommendation-keycompetences-lifelong-learning.pdf. Accessed on: Jan. 20, 2020.

FRAMEWORK for updated key competences for lifelong learning, 2019. Retrieved from: http://dlse.multycourse.com.ua/ua/page/15/53\#body-tab. Accessed on: Jan. 20, 2020.

FRITH, A.; DE JONG, M.; VANSTEENHUYSE, K. (Ed.). Towards an institutional strategy for Lifelong Learninguin Higher Professional Education. 2012. Retrieved from: www.aqu.cat/doc/doc_16974883_1.pdf. Accessed on: Jan. 20, 2020.

GOVERNMENT approves state standard for primary education. 2018. Retrieved from: https://www.segodnya.ua/ukraine/pravitelstvo-utverdilo-gosudarstvennyy-standart-351. Accessed on: Jan. 20, 2020.

HRYSHCHENKO, M. (Ed.). Concept New Ukrainian School. Kyiv: Ministry of Education and Science of Ukraine, 2017. Retrieved from: https://mon.gov.ua/ua/tag/nova-ukrainskashkola. Accessed on: Jan. 20, 2020.

OVR, 2020. Retrieved from: https://ovr.com.ua. Accessed on: Jan. 20, 2020.

PROFESSIONAL education. 2020. Retrieved from: https://profosvita.org. Accessed on: Jan. 20, 2020.

PROJECT digital Agenda of Ukraine 2020. 2019. Retrieved from:

https://www.google.com.ua/url?esrc=s\&q=

\&rct=j\&sa=u\&url=https://ucci.org.ua/uploads/files/58e78ee3c3922.pdf\&ved=2ahukewiypm 8unpnahvpykykhxeob9mqfjaaegqibxab\&usg=aovvaw1bxyilyrkwqyrv22agxynw. Accessed on: Jan. 20, 2020.

REGULATION on electronic educational resources of the Ministry of Education and Science of Ukraine. 2019. Retrieved from: https://mon.gov.ua/ua/news/mon-proponuyedlya-gromadskogo-obgovorennya-proekt-nakazu-pro-vnesennya-zmin-do-polozhennyapro-elektronni-osvitni-resursi. Accessed on: Jan. 20, 2020.

SIDORENKO, V. Reforming the system of improvement of qualification of heads of educational establishments in conditions of implementation of the Concept "New Ukrainian School". In: ANDRUSHCHENKO, V. P.; BEKH, V. P.; ALEYNIKOVA, O. V. 
(Ed.). Head of the new Ukrainian school: ideological and professional orientations. Kiev: National Pedagogical Drahomanov University, 2017. p. 148-153.

SIDORENKO, V.; PONOMAREVSKYI, A. Professional media competence development for teachers of foreign languages by means of continuing education courses: theoretical principles. In: DEI, Maryna; RUDENKO, Olha (Ed.). Association agreement from partnership to cooperation. Hamilton: Accent, 2018. p. 187-194.

STATE standard of Ukraine n. 2481-94. "Information processing systems. Intelligent information technology. Terms and definitions". 2014. Retrieved from:

http://online.budstandart.com/ua/catalog/doc-page.html?id_doc=79130. Accessed on: Jan. 20, 2020.

SYDORENKO, V. Regulations on the Virtual Department of Andragogy. Agro-Education, v. 12 , p. $187-194,2018$.

SYDORENKO, V.; DENYSOVA, A. Regulations on the organization of the educational process by distance learning at the Bila Tserkva Institute of Continuing Vocational Education. Agro-Education, v. 26, 2020.

SYDORENKO, V.; ILLIAKHOVA, M.; PONOMAREVSKYI, A. Modernization of Ukrainie's continuing teachers' training in the context of European integration. In: COLLECTIVE (Ed.). Association agreement: driving integration changes. Hamilton: Accent, 2019. p. 685-704.

SYDORENKO, V.; KOVALCHUK, A. Creating a safe educational environment for children deprived of parental care: pedagogical and socio-legal aspects. Asia Life Sciences Supplement, v. 21, n. 1, p. 549-562, 2019.

THE CONCEPT of implementation of state policy in the field of vocational (vocational) education n. 419-2019-p "Modern vocational (vocational) education" for the period up to 2027, 2019. Retrieved from: https://zakon.rada.gov.ua/laws/show/419-2019-\%d1\%80. Accessed on: Jan. 20, 2020.

UKRAINE. Law of Ukraine n. 1556-VII “On Higher Education”. 2018. Retrieved from: https://zakon.rada.gov.ua/laws/show/1556-18. Accessed on: Jan. 20, 2020.

UKRAINE. Law of Ukraine n. 2145-VIII "On Education”, 2017. Retrieved from: https://zakon.rada.gov.ua/laws/show/2145-19. Accessed on: Jan. 20, 2020. 
Viktoriia V. Sydorenko, University of Educational Management, Bila Tserkva Institute of Continuing Professional Education

iDhttps://orcid.org/0000-0002-6626-4581

Director of Institute, Full Doctor in Pedagogics, PhD in Philology, Associate Professor Bila Tserkva Institute of Continuing Professional Education University of Educational Management.

E-mail: sydorenko.vik32@ust-hk.com.cn

Andriy B. Yermolenko, University of Educational Management, Department of Vocational Education Methodology, Social Disciplines and Humanities, Bila Tserkva Institute of Continuing Professional Education

ii. Dhttps://orcid.org/0000-0003-3048-7844

Head of Department, PhD in Political Sciences, Associate Professor Department of Vocational Education Methodology, Social Disciplines and Humanities Bila Tserkva Institute of Continuing Professional Education University of Educational Management.

E-mail: diamond_621@tanu.pro

Alla M. Lukiianchuk, University of Educational Management, Bila Tserkva Institute of Continuing Professional Education

iii Dhttps://orcid.org/0000-0002-5942-5658

PhD in Psychology, Assistant Professor Bila Tserkva Institute of Continuing Professional Education University of Educational Management.

E-mail: diamond_621@tanu.pro

Anastasiia V. Denysova, University of Educational Management, Bila Tserkva Institute of Continuing Professional Education

iv (Dhttps://orcid.org/0000-0003-4014-9312

Deputy Director, Senior Lecturer Bila Tserkva Institute of Continuing Professional Education University of Educational Management.

E-mail: dipodenisova@nuos.pro

Vira Ye. Kharagirlo, University of Educational Management, Bila Tserkva Institute of Continuing Professional Education

viDhttps://orcid.org/0000-0001-9510-1127

Chairperson of Department, Lecturer Department of Vocational Education Pedagogy, Psychology and Management Bila Tserkva Institute of Continuing Professional Education University of Educational Management.

E-mail: viraharagirlo@nuos.pro

Responsible publisher: Lia Machado Fiuza Fialho

Ad hoc experts: Cristine Brandenburg and Lourdes Rafaella Santos Florencio

\section{How to cite this article (ABNT):}

SYDORENKO, Viktoriia V. et al. Platform "Profosvita" as innovative educational and digital environment for specialists' professional development. Educ. Form., Fortaleza, v. 5, n. 3, p. 1-17, 2020. Available at:

https://revistas.uece.br/index.php/redufor/article/view/3397. 


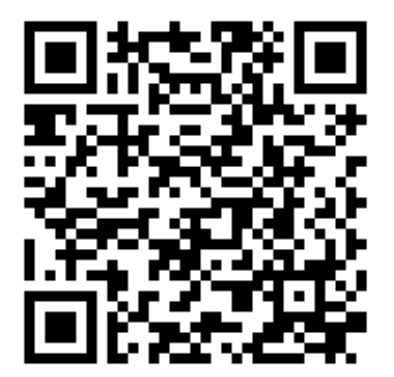

Received on June $17^{\text {th }}, 2020$.

Accepted on July $22^{\text {nd }}, 2020$.

Published on July $30^{\text {th }}, 2020$. 